\title{
Designing A Performance Measurement Tools at SMASH.ID Digital Startup with Balanced Scorecard Method
}

\author{
Gilang Mangestika ${ }^{1, *}$ Sari Wulandari ${ }^{2}$ Rio Aurachman ${ }^{3}$, Putra Fajar Alam ${ }^{4}$ \\ ${ }^{1}$ Universitas Telkom \\ ${ }^{2}$ Universitas Telkom \\ ${ }^{3}$ Universitas Telkom \\ ${ }^{4}$ Universitas Telkom \\ *Corresponding author.Email: gilangmanges@gmail.com
}

\begin{abstract}
SMASH.ID is one of the digital startups that provides applications to connect garbage banks, customers and the government. SMASH.ID in 2018 was not maximal in achieving its targets. This is because the strategy used is considered to be less effective. The purpose of this study is to find out how the performance of digital startup SMASH.ID in 4 balanced Scorecard perspectives. The method used in processing data in this research was the Analytical Hierarchy Process (AHP). The data used in this study are primary data and secondary data. The results of weighting showed that the most influential perspective was the customer's perspective with a percentage of $27 \%$. In addition, the assessment carried out using BSC found that the performance of SMASH.ID was in good category, with a rating scale of $72 \%$
\end{abstract}

Keywords: Strategy, Startup, Analytical Hierarchy Process, Balanced Scorecard

\section{INTRODUCTION}

According to Deputy for Infrastructure Bekraf Hari Sungkari when met by a team from KompasTekno, the percentage of failure of a startup reached 90\% [1]. Only $10 \%$ of startups have survived in Indonesia. SMASH.ID (online waste management system) is one of the startups that have survived today. Founded in January 2015, SMASH.ID is a web and mobile based application service provider that aims to support operational activities of waste banks throughout Indonesia. This digital startup connects parts that have roles in waste management such as communities, government, waste banks, and waste managers. SMASH.ID is divided into 3 parts, namely banksampah.id, mysmash, and e-smash. Banksampah.id serves to connect registered waste banks in Indonesia. Banksampah.id has several features such as managing customers and transactions, managing waste categories, and reporting \& historical transactions. Whereas my smash has 4 main functions that are useful for customers of waste banks. The feature features such as checking the location of the nearest garbage bank, information on the category of garbage and its price, picking up trash, and reimbursing garbage cans through smart bins.

Figure 1 and Figure 2 explain how the conditions of the Customer and the Waste Bank used the application from SMASH.ID in 2018. The garbage bank that is active using the SMASH.ID application is only 1245 out of 5475 garbage banks that use the SMASH.ID application. Customers who actively use the application have only reached $50 \%$ of the 56 existing customers. It showed that the strategy carried out by SMASH.ID is still not effective in making the existing system work properly based on fig. 1 . and fig. 2 .

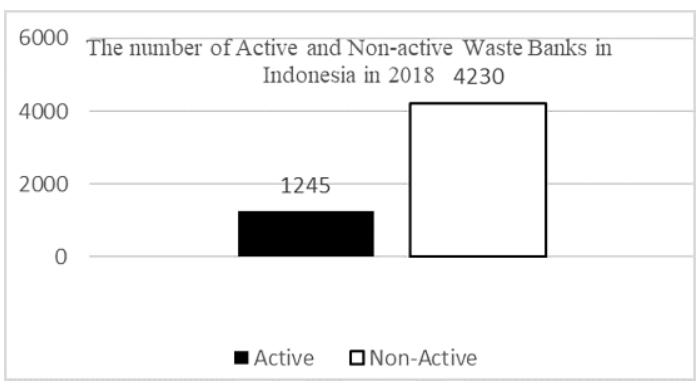


Figure 1 Number of active and non-active waste banks in indonesia in 2018.

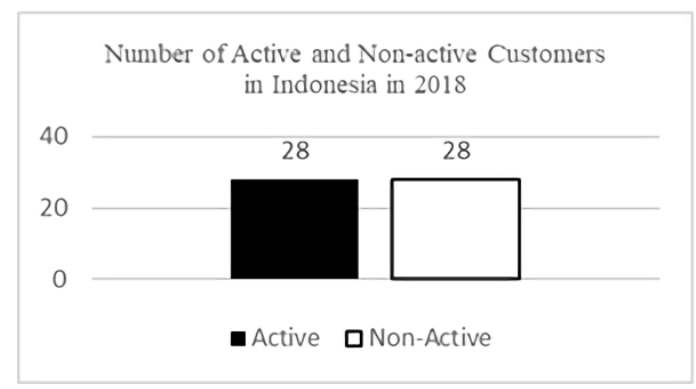

Figure 2 Number of active and non-active waste banks in indonesia in 2018.

According to the results of interviews with SMASH.ID's CEO, the company's management is still facing several issues that could contribute to the startup's failure. SMASH.ID establishes a Smash Knowledge Center division to handle current human capital, but the function of the division is still considered not to be optimal. It is caused that the development carried out is still based on the experience of training that has been carried out by the team. Existing training depends on what the team has, not based on what is needed by the startup. In other hand, what was done by the team in solving the problem still did not have a Standard Operating Procedure (SOP). Every issue received by SMASH.ID is only included in two types of problems, namely minority and majority. There is no specific process in resolving existing problems. Every problem is resolved when the person is having time to complete it. Then from the external side, like a garbage bank, there are still difficulties in using the application provided by SMASH.ID. while the activity of the waste bank in transacting digitally has an important role in SMASH.ID's income. Efforts made such as socialization to the public about the use of this e-smash have not yet produced the expected results. According to [2] the success of a startup can be seen from the achievement of set targets. The use of strategies that are in accordance by startup conditions also needs to be considered. Therefore, strategic management tools are needed. One of the strategic management tools that can be used is the Balanced Scorecard.

The Balanced Scorecard was first introduced by Kaplan and Norton. The perspective of balanced scorecard is good because it is not only financial, but also non-financial. There are 4 perspectives used in the Balanced Scorecard, namely finance, customers, growth and learning, and internal business processes. This balanced scorecard helps to measure and control organizations, both on the management and members of the organization.

\section{METHODS}

\subsection{Balanced Scorecard}

According to [3], the Balanced Scorecard consists of two words, namely the Balanced and Scorecard. The scorecard is defined as a scorecard, meaning the score card that will be used to plan the score that is realized in the future. In other hand, the balance means balanced, to measure executive performance in a balanced manner from sharing dimensions namely short and long term financial and non-financial, internal and external. According to [4], the Balanced Scorecard is a performance measurement system that focuses on financial and non-financial aspects by looking at 4 balanced scorecard perspectives, namely finance, customers, learning and employee growth, and internal business processes.

[5]states that the balanced scorecard is a performance management tool that can help organizations to translate their vision and strategy into action by utilizing a set of financial, non-financial indicators which are all intertwined in a causal relationship. From the three expert opinions, it can be concluded that the definition of the Balanced Scorecard is a performance management tool to help startups or organizations whose goals have not been achieved so that the strategies used are in accordance with financial, customer, learning and growth, and internal business processes. [6] explain there are four perspectives in BSC, namely as follows:

\subsubsection{Financial Perspective (Financial)}

Financial perspective is related to income and expenses made by the company. The company must manage its finances well, so that financial stability is still achieved. The strategy used in financial management varies depending on where the company is located.

\subsubsection{Customer Perspective}

[7]divide the customer's perspective into two measurement groups, namely: customer core measurement and customer value prepositions. customer core measurement is used to measure how companies meet customer needs.

\subsubsection{Internal Business Process Perspective}

In this perspective the company identifies any part of the internal business process that needs to be seeded. The company can assess whether the product offered is in accordance with customer needs. 


\subsubsection{Growth and Learning Perspective}

According to [6]there are three categories that are very important in the perspective of learning and growth, namely: employee competency, technology infrastructure, and motivation

\subsection{Analytical Hierarcy Process (AHP)}

AHP is a decision-making method developed by a mathematics professor at the University of Pittsburgh, Thomas L. Saaty. According to [8], hierarchy is defined as a representation of a complex problem in a multilevel structure where the first level is a goal, followed by a factor level, criteria, sub criteria, and so on down to the last level of the alternative. AHP is a functional hierarchy with input in the form of perception. The AHP model is a method that is carried out with subjective long angles, where each criterion depends on people who are considered experts or understanders in the field.

\section{RESULTS AND DISCUSSION}

\subsection{Translation of SMASH.ID's Vision, Mission and Strategy into KPI (Key Performance Indicator)}

The description of the Startup Vision, Mission and Strategy was carried out by using the FGD method or Focus Group Discussion with several speakers from SMASH.ID who were the decision makers.From the results of the FGD, a description of the vision, mission and strategy of the startup was obtained into the strategic objectives, CSF (Critical Success Factors), and KPI (Key Performance Indicators) in the four Balanced Scorecard perspectives. The following were the results of the description of the vision, mission and strategic strategy on table 1 ..

Table 1. Results of Translation of Vision, Mission and Strategy SMASH.ID

\begin{tabular}{|c|c|c|c|c|}
\hline $\begin{array}{c}\text { Perspectiv } \\
\text { e }\end{array}$ & $\begin{array}{c}\text { Strategic } \\
\text { target }\end{array}$ & CSF & KPI & Source \\
\hline \multirow[t]{3}{*}{ Customer } & \multirow{3}{*}{$\begin{array}{l}\text { Increase the } \\
\text { use of } \\
\text { SMASH.ID } \\
\text { and expand } \\
\text { to other } \\
\text { markets }\end{array}$} & $\begin{array}{l}\text { Customer } \\
\text { satisfaction }\end{array}$ & $\begin{array}{l}\text { Percentage } \\
\text { of customer } \\
\text { complaints }\end{array}$ & \multirow{5}{*}{$\begin{array}{l}{[9],} \\
{[10]} \\
\text { FGD } \\
(28 \\
\text { Februar } \\
\text { i 2019) }\end{array}$} \\
\hline & & $\begin{array}{l}\text { Startup } \\
\text { reputation }\end{array}$ & $\begin{array}{l}\text { Customer } \\
\text { Growth } \\
\text { (full service } \\
\text { user) }\end{array}$ & \\
\hline & & & Traction & \\
\hline \multirow[t]{2}{*}{ Finance } & \multirow[t]{2}{*}{$\begin{array}{l}\text { Increased } \\
\text { revenue }\end{array}$} & \multirow[t]{2}{*}{ Projectbase } & $\begin{array}{l}\text { Amount of } \\
\text { Grants }\end{array}$ & \\
\hline & & & $\begin{array}{l}\text { Number of } \\
\text { Smart Drop } \\
\text { Box } \\
\text { Installed }\end{array}$ & \\
\hline
\end{tabular}

\begin{tabular}{|c|c|c|c|}
\hline & & $\begin{array}{l}\text { Transaction } \\
\text { base }\end{array}$ & $\begin{array}{l}\text { Use of E- } \\
\text { money } \\
\text { smash pay }\end{array}$ \\
\hline \multirow[t]{2}{*}{$\begin{array}{l}\text { Internal } \\
\text { Business } \\
\text { Processes }\end{array}$} & \multirow{2}{*}{$\begin{array}{l}\text { Operational } \\
\text { Process } \\
\text { Optimizatio } \\
n\end{array}$} & $\begin{array}{l}\text { Marketing } \\
\text { Activity } \\
\text { Efficiency }\end{array}$ & $\begin{array}{l}\text { Cooperatio } \\
\mathrm{n} \text { Initiation } \\
\text { Cycle Time }\end{array}$ \\
\hline & & $\begin{array}{l}\text { Application } \\
\text { Developmen } \\
\mathrm{t}\end{array}$ & $\begin{array}{l}\text { Frequency } \\
\text { of } \\
\text { Application } \\
\text { Updates }\end{array}$ \\
\hline \multirow[t]{2}{*}{$\begin{array}{l}\text { Learning } \\
\text { and Growth }\end{array}$} & \multirow[t]{2}{*}{$\begin{array}{l}\text { Increased } \\
\text { Internal } \\
\text { Skills }\end{array}$} & $\begin{array}{l}\text { Team } \\
\text { Satisfaction }\end{array}$ & $\begin{array}{l}\text { Fulfillment } \\
\text { of Team } \\
\text { Expectation } \\
\mathrm{s}\end{array}$ \\
\hline & & $\begin{array}{l}\text { Knowledge } \\
\text { Centre } \\
\text { Functional }\end{array}$ & $\begin{array}{l}\text { Number of } \\
\text { Training }\end{array}$ \\
\hline
\end{tabular}

\subsection{Weighting the Balanced Scorecard using AHP}

The weighting of the four perspectives was obtained by calculating the results of the importance questionnaire from four respondents. Respondents selected to fill out this questionnaire were decision makers from the startup. The results of the questionnaire from each respondent were used to obtain the initial matrix from the four perspectives. Then, the results of the matrix were carried out normalization and consistency test calculations. The following were the results of the weighting of strategic targets, CSF, and KPI from each perspective that has been normalized using AHP based on table 2 .

Table 2. KPI Weighting Results

\begin{tabular}{|c|c|c|c|c|c|}
\hline \multicolumn{2}{|c|}{ Perspective } & \multicolumn{2}{|c|}{ Strategic target } & \multirow{2}{*}{$\begin{array}{l}\text { CSF } \\
\text { Name }\end{array}$} & \multirow{2}{*}{$\begin{array}{c}\text { KPI } \\
\text { Weight }\end{array}$} \\
\hline Name & Weight & Name & Name & & \\
\hline \multirow[t]{3}{*}{ Customer } & \multirow[t]{3}{*}{$27 \%$} & \multirow{3}{*}{$\begin{array}{l}\text { Increase } \\
\text { the use } \\
\text { of } \\
\text { SMASH } \\
\text {.ID and } \\
\text { expand } \\
\text { to other } \\
\text { markets }\end{array}$} & $\begin{array}{l}\text { Customer } \\
\text { satisfaction }\end{array}$ & $\begin{array}{l}\text { Percentage } \\
\text { of customer } \\
\text { complaints }\end{array}$ & $84 \%$ \\
\hline & & & $\begin{array}{l}\text { Startup } \\
\text { reputation }\end{array}$ & $\begin{array}{l}\text { Customer } \\
\text { Growth } \\
\text { (full service } \\
\text { user) }\end{array}$ & $6 \%$ \\
\hline & & & & Traction & $10 \%$ \\
\hline \multirow[t]{3}{*}{ Finance } & \multirow[t]{3}{*}{$24 \%$} & \multirow{3}{*}{$\begin{array}{l}\text { Increase } \\
\mathrm{d} \\
\text { revenue }\end{array}$} & Projectbase & $\begin{array}{l}\text { Amount of } \\
\text { Grants }\end{array}$ & $8 \%$ \\
\hline & & & & $\begin{array}{l}\text { Number of } \\
\text { Smart Drop } \\
\text { Box } \\
\text { Installed }\end{array}$ & $53 \%$ \\
\hline & & & $\begin{array}{l}\text { Transaction } \\
\text { base }\end{array}$ & $\begin{array}{l}\text { Use of E- } \\
\text { money / } \\
\text { smash pay }\end{array}$ & $39 \%$ \\
\hline \multirow[t]{2}{*}{$\begin{array}{c}\text { Internal } \\
\text { Business } \\
\text { Processes }\end{array}$} & \multirow[t]{2}{*}{$25 \%$} & \multirow{2}{*}{$\begin{array}{l}\text { Operatio } \\
\text { nal } \\
\text { Process } \\
\text { Optimiz } \\
\text { ation }\end{array}$} & $\begin{array}{l}\text { Marketing } \\
\text { Activity } \\
\text { Efficiency }\end{array}$ & $\begin{array}{l}\text { Cooperatio } \\
\mathrm{n} \text { Initiation } \\
\text { Cycle Time }\end{array}$ & $34 \%$ \\
\hline & & & $\begin{array}{l}\text { Application } \\
\text { Developme } \\
\text { nt }\end{array}$ & $\begin{array}{l}\text { Frequency } \\
\text { of } \\
\text { Application } \\
\text { Updates }\end{array}$ & $66 \%$ \\
\hline $\begin{array}{l}\text { Learning } \\
\text { and } \\
\text { Growth }\end{array}$ & $23 \%$ & $\begin{array}{l}\text { Increase } \\
\mathrm{d} \\
\text { Internal }\end{array}$ & $\begin{array}{l}\text { Team } \\
\text { Satisfaction }\end{array}$ & $\begin{array}{l}\text { Fulfillment } \\
\text { of Team } \\
\text { Expectation }\end{array}$ & $21 \%$ \\
\hline
\end{tabular}




\begin{tabular}{|l|l|l|l|l|l|}
\hline & Skills & & s & \\
\cline { 3 - 5 } & & $\begin{array}{l}\text { Knowledge } \\
\text { Centre } \\
\text { Functional }\end{array}$ & $\begin{array}{l}\text { Number of } \\
\text { Training }\end{array}$ & $79 \%$ \\
\hline
\end{tabular}

\subsection{Performance Measurement of SMASH.ID}

At this stage, KPI is calculated to assess all startup performance in each perspective. After the formulation has been determined for each KPI, the next step is to take the data needed from the startup to be calculated and compared to the target of the startup based on table 3 and table 4 .

Table 3. Results of SMASH.ID Performance Measurement

\begin{tabular}{|c|c|c|c|c|c|c|c|c|c|}
\hline Perspective & KPI & Weight & Target & Realization & Unit & Achievement & $\begin{array}{c}\text { Target } \\
\text { Indicator } \\
\text { Category }\end{array}$ & Score & Value \\
\hline \multirow[t]{3}{*}{ Customer } & $\begin{array}{l}\text { Percentage of customer } \\
\text { complaints }\end{array}$ & 0,84 & $10 \%$ & $2 \%$ & $\%$ & $9 \%$ & Maximum & 5 & 4,19 \\
\hline & $\begin{array}{l}\text { Customer Growth (full } \\
\text { service user) }\end{array}$ & 0,06 & $35 \%$ & $4 \%$ & $\%$ & $11 \%$ & Minimum & 1 & 0,06 \\
\hline & Traction & 0,10 & 10 & 9 & - & $90 \%$ & Minimum & 4 & 0,39 \\
\hline \multicolumn{9}{|c|}{ Customer Perspective Value } & 4,65 \\
\hline \multirow[t]{3}{*}{ Finance } & Amount of Grants & 0,08 & $\begin{array}{l}\text { Rp. } \\
200.000 .000\end{array}$ & $\begin{array}{l}\text { Rp. } \\
221.350 .000\end{array}$ & $\mathrm{Rp}$ & $111 \%$ & Minimum & 5 & 0,38 \\
\hline & $\begin{array}{l}\text { Number of Smart Drop Box } \\
\text { Installed }\end{array}$ & 0,53 & 70 & 101 & Unit & $144 \%$ & Minimum & 5 & 2,65 \\
\hline & $\begin{array}{l}\text { Use of E-money / smash } \\
\text { pay }\end{array}$ & 0,39 & 1000 & 172 & Transaction & $17 \%$ & Minimum & 1 & 0,39 \\
\hline \multicolumn{9}{|c|}{ Financial Perspective Value } & 3,43 \\
\hline \multirow[t]{2}{*}{$\begin{array}{ll}\text { Internal } & \text { Business } \\
\text { Processes } & \end{array}$} & $\begin{array}{l}\text { Cooperation } \\
\text { Cycle Time }\end{array}$ & 0,34 & 60 & 38 & Day & $63 \%$ & Maximum & 4 & 1,35 \\
\hline & $\begin{array}{l}\text { Frequency of Application } \\
\text { Updates }\end{array}$ & 0,66 & 36 & 88 & $\begin{array}{ll}\text { Times } & / \\
\text { year }\end{array}$ & $244 \%$ & Maximum & 1 & 0,66 \\
\hline \multicolumn{9}{|c|}{ Internal Business Process Perspective Value } & 2,02 \\
\hline \multirow[t]{2}{*}{ Learning and Growth } & $\begin{array}{l}\text { Fulfillment of } \\
\text { Expectations }\end{array}$ & 0,21 & $75 \%$ & $82 \%$ & $\%$ & $109 \%$ & Minimum & 5 & 1,07 \\
\hline & Number of Training & 0,79 & 12 & 11 & $\begin{array}{ll}\text { Times } & 1 \\
\text { year }\end{array}$ & $92 \%$ & Minimum & 4 & 3,14 \\
\hline \multicolumn{9}{|c|}{ Learning and Growth Perspective Value } & 4,21 \\
\hline
\end{tabular}

Table 4. Overall SMASH.ID Performance

Measurement.

\begin{tabular}{|l|l|l|l|}
\hline \multicolumn{1}{|c|}{ Perspective } & Weight & Score & Value \\
\hline Customer & 0,27 & 4,65 & 1,28 \\
\hline Finance & 0,24 & 3,43 & 0,84 \\
\hline Internal Business Processes & 0,25 & 2,02 & 0,50 \\
\hline Learning and Growth & 0,23 & 4,21 & 0,98 \\
\hline Overall Value & & 3,6 \\
\hline
\end{tabular}

\section{CONCLUSIONS}

The following is a description of the measurement results at SMASH.ID digital startup using the Balanced Scorecard method:

\subsection{Financial Perspective}

From a financial perspective, the strategic goal determined by the startup is to increase revenue. From the strategic objectives obtained by two Critical Success Factors (CSF), namely the Project Base with KPI, the number of grant funds, and the number of smart drop boxes installed, as well as the Transaction Base with KPI using e-money (smash pay). Obtained 2 KPIs that have met the target and 1 KPI that has not been able to reach the target of using e-money. The financial perspective obtains a performance value of 3.43 (sufficient) with an acquisition scale of $69 \%$.

\subsection{Customer Perspective}

From the customer's perspective, the targets determined by the startup increase the use of SMASH.ID and need to go to other markets. The strategic objectives were obtained by two Critical Success Factors (CSF), namely customer satisfaction with the KPI percentage of customers, as well as startups with customer growth KPIs (full -service users) and attractiveness. Then it can be said that having one KPI that has reached the target and two KPIs that have failed to meet the target. With a 93 percent acquisition scale, the consumer perspective receives an output score of 4.65 (Very Good).

\subsubsection{Internal Business Process Perspective}

From the business process perspective, the internal target determined by the startup is the optimization of the operational process. The strategic objectives were obtained by two Critical Success Factors (CSF) which consist of the efficiency of marketing activities with KPI cycle time initiatives and application development with KPI frequency scale applications. In this perspective there are no KPIs that can meet their targets. The internal business process perspective reaches a 
performance value of 2.02 (Less) with an acquisition scale of $40 \%$.

\subsubsection{Learning and Growth Perspective}

The increasing in internal skills is essential from the standpoint of learning and the achievement of the startup's strategic goals. Two critical success factors (CSF) were extracted from these strategic goals, namely team satisfaction with KPI fulfillment and KPI amount of preparation. From these strategic objectives, two critical success factors (CSF) were obtained, namely team satisfaction with KPI fulfillment of team expectations, and functional knowledge center with KPI amount of training. Only $1 \mathrm{KPI}$ can meet its target. It is team satisfaction. The learning and growth perspective got a performance value of 4.21 (Good) with an achievement scale of $84 \%$.

Overall, SMASH.ID digital startup has a performance value of 3.6 (Good) with a $72 \%$ achievement scale. The proposed strategies that can be carried out by startup are as follows:

1. SMASH.ID should use the balanced scorecard to monitor startup conditions. It is suitable for startups because it recognizes both financial and non-financial factors, as well as internal and external factors.

2. Startups should boost their performance because many key performance indicators (KPIs) have yet to reach the goal. The startup is excessively concentrated on one KPI, resulting in the inability to achieve other objectives.

\section{REFERENCES}

[1] O. Yusuf, "Kompas.com," 6 April 2016. [Online]. Available:

https://tekno.kompas.com/read/2016/04/06/094546
47/Startup.Banyak.yang.Gagal.Bekraf.Siapkan.BE K-UP .

[2] P. A. Wickham, Strategic Entrepreneurship, Essex: Pearson Education Limited, 2004.

[3] Mulyadi, Balanced Scorecard, Jakarta: Salemba Empat, 2007.

[4] Sukardi, Balanced Scorecard, Jakarta: Bumi Aksara, 2003.

[5] Luis dan P. A. Biromo, Step by step in cascading balanced scorecard to functional scorecards, Jakarta: Gramedia Pustaka Utama, 2007.

[6] R. S. Kaplan dan D. Norton, The Balanced Scorecard: Translating Strategy Into Action., Massachusetts: Harvard Business School Press, 1996.

[7] R. S. Kaplan dan D. P. Norton, The Strategy Focused Organization: How Balanced Scorecard Companies Thrive in the New Business Environment, Massachusetts: Harvard Business School Press, 2001.

[8] T. L. Saaty, Pengambilan Keputusan Bagi Para Pemimpin, Proses Hirarki Analitik untuk Pengambilan Keputusan dalam Situasi yang Kompleks. Setiono L, Penerjemah : Peniwati K. Editor, Jakarta: PT. Pustaka BInaman Pressindo, 1993.

[9] M. Martello, J. G. Watson dan M. J. Fischer, "Implementing a balanced scorecard in a not-forprofit organization," J. of Business \& Economics Research Vol 6 No. 9, pp. 67-80, 2008.

[10]C. Scholey dan K. Schobel, "Performance Measurement for Non-Profit Organizations," Chartered Professional Accountants Canada, 2016. 